\title{
THE CONTRIBUTION OF APPLIED PSYCHOLOGY FOR EDUCATIONAL MANAGEMENT ISSUE
}

\author{
Ivan Riyadi \\ Universitas Islam Negeri Raden Fatah Palembang, Indonesia \\ ivanriyadi_uin@radenfatah.ac.id
}

\begin{abstract}
This article discusses education management in frame of psychology. The education management is a factual behavior of the psychological discipline that is depicted in through the analysis of the behavior system of the school organization involving a number of components. In the application of psychology in education management is a part of the element that is not stuck in the view of uniformity that practically diversity by each education leadership. Each educational institution is a singularity that relates to the differences in the nature and condition of each component of the psychological system. To get an intact picture in this article, then used a qualitative approach with literature research design. The results of the study indicated that such an understanding is to be aware of educational practitioners of the importance of psychology universally, through culture, and psychology and social. Then the role of education management is very important especially educational institutions tailored to the psychological conditions of managerial and the needs of students.
\end{abstract}

Keywords; education, management, psychology.

Abstrak: Artikel ini membahas manajemen pendidikan dalam bingkai psikologi. manajemen pendidkan merupakan perilaku faktual dari disiplin keilmuan psikologi yang tergambarkan dalam melalui analisis sistem perilaku organisasi sekolah yang melibatkan sejumlah komponen. Dalam penerapan psikologi pada manajemen pendidikan merupakan bagiaan dari unsur yang tidak terjebak dalam pandangan keseragaman yang praktis keragaman oleh masing-masing kepemimpinan pendidikan. Setiap lembaga pendidikan bagian singularitas yang berhubungan pada perbedaan dalam sifat dan kondisi masing-masing komponen sistem psikologi. Untuk mendapatkan gambaran yang utuh dalam artikel ini, maka digunakan pendekatan kualitatif dengan desain penelitian literatur. Hasil penelitian menujukkan bahwa Pemahaman demikian adalah dapat menyadari praktisi pendidikan akan pentingnya psikologi secara Universal, melalui budaya, dan psikologi dan sosial. Maka, peran manajemen pendidikan sangat penting terutama lembaga pendidikan yang disesuaikan dengan kondisi psikologis manajerial dan kebutuhan siswa.

Kata kunci; manajemen, pendidikan, psikologi.

(C) Author et al, Licensee Psychosophia, Islamic Psychology Program, IAIN Syaikh Abdurrahman Siddik Bangka Belitung, Indonesia. Psychosophia strongly support the Open Access Initiative. Abstract and full text of the article published by Psychosophia are freely accessible to everyone immediately after publication. This is an Open Access article distributed under the terms of the Creative Commons Attribution License, which permits unrestricted use, distribution, and reproduction in any medium, provided the original work is properly cited.
Submission Date Review Date Publish Date
: February 18, 2020

; April 16, 2020

: June 01, 2020 


\section{Pendahuluan}

Psikologi jika ditelusuri dan dipelajari lebih dalam, maka akan tampak usahanya dalam memahami perilaku manusia (Jahja, 2011). Selain itu, kebanyakan orang memandang psikologi merupakan ilmu jiwa yang berkaitan dengan ilmu kejiwaan (Taufiq, 2007). Dalam perkembangannya pun, psikologi lantas meluas mencakup psikologi pendidikan, psikologi klinis, psikologi sosial, psikologi perkembangan, psikologi lintas budaya, dan lain sebagainya (Pieter, 2017). Psikologi yang diterapkan pada bidang-bidang kehidupan dapat mengarahkan seseorang pada tujuan yang lebih baik. Salah satu contohnya dikenal dengan motivasi, dimana ia dapat mendorong seseorang untuk melakukan dan mempertahankan (konsisten) dalam sikap dan perilaku.

Ilmu perilaku yang membentuk sebuah proses mental seseorang akan menuntut sebuah keadaan yang lebih baik dan sempurna (Roqib, 2009). Sebagai contoh, seseorang yang tidak berminat dengan pelajaran akan tetapi dengan didorong oleh keinginan dan rasa tanggungjawab. Kemudian, ada peraturan yang berlaku akan mengakibatkan seseorang untuk mengikuti proses pembelajaran agar dapat diselesaikan dengan baik. Kemudian dapat dinyatakan lulus sebagai pelajar yang mengenyam pendidikan di Indonesia.

Kalau melihat Indonesia yang dari kekayaan dan letak geografis maka menjadi suatu kesyukuran sebagai masyarakat majemuk (Syafi'i, 2012). Indonesia merupakan negara kepulauan yang memiliki banyak keragaman budaya, suku, bahasa, adat dan keyakinan. Nusantara terdiri secara garis besar yaitu struktur kesukuan, tingkat pendidikan, letak wilayah daerah. Keragaman tersebut dalam dunia pendidikan merupakan hal positif untuk menjadikan kekayaan khasah disiplin keilmuan. Keragaman di Nusantara terbingkai dalam Pancasila membentuk kerukunan, kedamaian, memfasilitasi suatu perbedaan, kesenjangan walaupun berbeda tetap satu (Riyadi, 2019).

Pendidikan dapat membimbing kehidupan manusia yang memiliki kemahiran secara individual dan sosial yang berinteraksi dengan alam supaya menjadi individu yang bertanggungjawab (Jalaluddin, 1997). Kemudian senada dengan Sa'ud (2009) konsep pendidikan untuk membantu pengembangan kemampuan manusia dalam menjalankan perintah dan amanah. Kemudian mempengarui fisik, emosional, perilaku dan keyakinan manusia kepada sang pencipta.

Dari sisi konseptual pendidikan berguna dengan adanya implementasi yang searah dengan tujuan dalam manajemen pendidikan (Sufyarma, 2003). Dalam hal ini pendidikan mengajarkan kepada manusia untuk hidup lebih bijak, efektif dalam mengelola suatu tindakan agar terarah dalam pencerahan. Manajemen merupakan pengorganisasian dan pengendalian pemimimpin dalam merencanakan suatu tujuan yang efektif dan efesien (Muhaimin, 2015).

Manajemen menurut soebagio Atmodiwiro adalah ilmu yang menata sumber daya untuk mencapai tujuan yang telah dimufakati (Soebagio, 2002). Maka dalam hal ini manajemen memiliki posisi yang strategis di lembaga pendidikan untuk membentuk peserta didik yang telah disepakati dalam mancapai tujuan. 
eksplorasi dalam pengembangan manajemen pendidikan harus melihat dimensi kemanusiaan

Manejemen pendidikan dalam proses pengembangan potensi kemanusiaan yang memiliki korelasi terhadap dengan sistem pendidikan sehingga perlu lmencari referensi dalam membentuk manajemen pendidikan dalam aspek psikologi (Khodijah, 2011). Konsep psikologi memiliki kajian terhadap diri manusia baik secara fisik maupun perasaan. Kegiatan atau aktivitas manusia dalam sebuah perilaku memilki hubungan yang erat terhadap prosesi pada lembaa pendidikan. Dengan demikian melihat proses perkembangan manajemen dalam lembaga pendidikan Islm yang memperhatikan situasi dan perkembangan ilmu pengetahuan Psikologi dalam penerapat terhadap pendidikan, sebagai contoh yang berkembag dalam dunia pendidikan adalah pskologi belajar, emosional, spritual dan motivasi.

Perkembangan zaman yang berubah sangat pesat dan memiliki problematika dalam perkebangannya, maka manajemen pendidikann menjadi wadah untuk melahirkan dan menciptakan manusia yang memiliki daya saing. Manajemen pendidikan harus memiliki orientasi kepada sumber daya manusia yang unggul. Mandiri, inovasi. Dalam membentuk manusia yang unggul tentunya harus memperhatikan dimensi psikologi, tentunya psikologi yang nyaman sesuai yang diinginkan oleh tujuan pendidikan yang sesuai dengan arah dan keinginan bangsa Indonesia. Karena pentingnya pemahaman mengenai bagaimana implikasi dan fungsi tinjauan psikologi dalam manajemen pendidikan diperlukan kajian lebih lanjut terhadap hal tersebut, sehingga tulisan ini dibuat untuk melakukan tinjauan kritis terhadap manajemen pendidikan dalam perspektif psikologi.

Maka dalam hal ini yang menjadi kegelisahan akademik dalam penelitian adalah realitas penyelenggaraan manajemen pendidikan secara aspek subtantif pada tataran pengelolaan lembaga pendidikan masih belum tepat pada sasaran dan harapan nasinal pendidikan. Adapun untuk memahami pendidikan yang subtantif dan esensial diperlukan pendekatan psikolgi yang dapat dirumuskan masalah yang dapat memecahkan masalah tersebut. 1) Apa hakekat manajemen pendidikan. Dan 2) apa kajian Psikologi? 3) Sumbangsih psikologi pada manajemen pendidikan? Dari rumusan masalah tersebut, maka tujuan dari penelitian ini adalah merumuskan tentang peran psikologi dalam manejemen pendidikan dan memberikan rumusan hubungan manajemen pendidikan dan psikologi dalam kajian lembaga pendidikan. Tulisan ini selanjutnya mencoba untuk memaparkan psikologi dalam mengelola pendidikan yang bermutu dan berdaya saing.

Adapun sumber utama tulisan ini diperoleh melalui laporan penelitian khususnya yang telah diterbitkan baik berupa jurnal nasional, buku, e-book, selanjutnya cara dan standar yang digunakan penelitian literatur tersebut melalui tiga cara yaitu; pertama pengumpulan, kedua adalisis data, ketiga penarikan kesimpulan. Tanpa ingin mengklaim sebagai kemutlakan kebenaran hasil kajian, kita juga dituntut berupaya 
menemukenali rumusan tentang definisi agama, dari pendekatan kebahasaan hingga tinjauan istilah, secara substansial maupun fungsional.

\section{Hakekat Manajemen Pendidikan}

Manajemen secara bahasa dalam bahasa Inggris adalah pimpinan, pengelola. Bahasa latin memiliki 2 suku kata yaitu manus (tangan)dan agare (melaksanakan) Maka dengan demikian konsep administrasi pendidikan memiliki makna yang sama terhadap manajemen pendidikan karena berbicara tentang penglolaan pendidikan. Maka dengan ini manajemen pendidikan memiliki fungsi yang merencanakan dalam controling. Dalam konsep pelaksanaannya perlu diadakan balance dan cek untuk mengontrol kekurangan dan kelemahan dalam suatu manajemen pendidikan. Ketika mengetahui kelemahan dan kekurangan dalam suatu manajemen pendidikan maka dapat dilakukan suatu penilaian yang akan diraih.

Manajemen berasal dari kata to manage yang berarti mengatur. Pengaturan dilakukan mellalui proses dan diatur berdasarkan urutan dari fungsifungsi manajemen itu. Jadi manajemen itu merupakan suatu proses untuk mewujudkan tujuan yang diinginkan karena manajemen yang berarti mengatur maka banyak pertanyaan yang timbul seperti. manajemen diartikan sebagai pengaturan yang mengatur segala hal yang dilakukan oleh setiap orang seperti membuat suatu rencana seperti membuat suatu acara ataupun juga suatu perusahaan mereka menggunakan manajemen seperti manajemen keuangan ,rnanajemen waktu manajemen dan lainnya jadi manajemen juga dibutuhkan dalam kehidupan seseoarang.

Penilaian yang diraih adalah suatu kesuksesan dalam mengelola sumber daya manusia pada unsur pendidik dan kependidikan. Manajemen pendidikan adalah suatu tata cara pengelolaan dalam meningkatkan kemampuan sumber daya manusia dalam mengoraganisir kegiatan. Kegiatan-kegiatan dalam pendidikan berharap pada suatu tujuan dalam melaksanakan kurikulum, ketegaan, sarana dan prasarana, pembiayaan, dan dalam hubungan dengan eksternal kampus.

Manajemen merupakan sebuah seni yang mengatur proses pemanfaatan pada sumber daya manusia secara efektif yang dikukung pada oleh sumber-sumber lainya dalam suatu organisasi untuk mencapai tujuan. Manajemen pada umumnya dikaitkan dengan aktivitasaktivitas perencanaan, pengorganisasian, pengendalian, penempatan, pengarahan, pemotavasian, komunikasi dan pengambilan keputusan yang dilakukan oleh setiap organisasi dengan tujuan untuk mengoordinasikan berbagai sumber daya manusia.

Manajemen pendidikan merupakan agenda yang harus diselenggarakan dalam konsep merencanakan, mengelola dan evaluasi sumber daya pada lembaga pendidikan Islam yang secara efektif dan efisien untuk menggapai sebuat tujuan (Tilaar, 2006). Manajemen pendidikan didalamnya terkandung sub-sub komponen, planning, sistem pendidikan, tingkatan pendidikan, pengembangan pendidikan, administrasi, pembiayaan pendidikan, dan penelitian (Mudyahardjo, 2010). Manajemen pendidikan merupakan suatu proses yang berkaitan dengan 
pengelolaan memiliki kegunaan. Manajemen pendidikan memiliki beberapa unsur diantaranya adalah perencanaan, mengelola organisasi, saling koordinasi, dan memberikan semangat, dan melakukan controling.

Manajemen pendidikan terdiri dari beberapa ruang lingkup diantaranya adalah koordinasi setiap melaksanakan agenda dalam wadah organisasi, melaksanakan kegiatan berdasarkan tujuan pendidikan, manajemen yang mengikutsertakan banyak orang, baik wali, pendidik, peserta didik, dan orang lain dalam lembaga pendidikan (Sutisna, 1983; Pananrangi, 2017).

Maka dalam hal ini beberapa pengertian di atas mengenai manajemen pendidian dapat disimpulkan bahwa semua agenda, kurikulum, dengan memakai fasilitas dalam perencanaan, pembiayaan melalui proses tertentu yang dapat dikomunikasikan melalui controling, yang dievaluasi dalam beberapa kegiatan baik secara materil maupun sumber daya manusia untuk meraih cita-cita atau harapan dalam pendidikan.

\section{Kajian Psikologi}

Menurut Woodworth bahwa psikolgi menggambarkan beberapa batasan tertentut: Psychology can be defined as the science of the activities of the individual (psikologi adalah ilmu yang mempelajari tingkah laku manusia) (Woodworth, 1955). Dari pengertian tersebut bahwa tingkah laku manusia mencakup komunikasi dan interaksi sesama.

Psikologi merupakan disiplin ilmu yang mempelajari kegiatan-kegiatan atau tanda-tanda pada psikis yang menggambarkan tingkah laku manusia dan hewan diimplementasikan untuk menghadapi masalah-masalah yang dirasakan oleh manusia (Khodijah, 2011). Maka dalam hal ini bahwa kajian psikologi merupakan suatu kebutuhan dalam kajian manajemen yang khusus untuk mengenal perilaku manusia. Mengenal suatu perilaku dan sifat tentu diiringi sebuah pengetahuan, karena obejek tersebut yang dapat digunakan untuk mengetahui pokok-pokok dalam sebuah kajian bidang keilmuan dalam psikologi (Setiadi, 2016).

Syah mendefinisikan psikologi adalah suatu pengetahuan yang menerangkan perilaku dan sifat manusia yang tebuka dan tertutup pada sesama (Syah, 2010). Sehingga, dalam definisi tersebut merupakan bagian daripada lingkungan yang memiliku korelasi terhadap semua manusia, benda, kondisi lingkungan yang ada di sekeliling manusia. Kondisi manusia, benda, dan lingkungan merupakan objek dalam sebuah pengetahuan dan bidang disiplin keilmuan. Keberadaan objek sangat mendukung sekali dalam sebuah penelitian pengetahuan, sehingga tanpa adanya objek akan terjadi ketidak jelasan suatu bidang keilmu pengetahuan. Objek dari sebuah pengetahuan terdapat dua jenis yaitu objek material dan objek formal.

Objek material merupakan objek yang dilihat dari keseluruhan. Kemudian objek formal merupakan objek yang dilihat dari sebagian aspek saja. Sebagian aspek tersebut cendrung kepada aspek penting dan tidak penting dalam unsur-unsur psikologi (Purwanto, 2010). Objek material terdiri dari fakta-fakta dan gejala-gejala atau sumber-sumber yang riil untuk diteliti dan dipahami sebagai suatu 
pengetahuan. Kemudian objek formal yaitu sesuatu pengetahuan yang menggambarkan dari pengertian dan pembahasan dalam batasan sebagai ilmu yang saling berkaitan.

Maka dapat dibuat rumusan terhadap objek dalam kajian psikologi yang terdiri dari objek formal dan material. Objek formal merupakan objek yang terdiri dari manusia sendiri. Sedangkan objek material berupa segala bentuk yang memiliki korelasi terhadap manusia. Kemudian lebih lanjut bahwa psikologi merupakan suatu proses dalam pembentukan manusia dengan mempelajari psikis dan perilaku manusia terhadap lingkungan dalam kehidupan sehari-hari.

Pembentukan perilaku tersebut dapat dijadikan sebagai suatu sikap yang dapat memperkuat dan penuh tekad. Oleh karena itu seserang dapat dengan mudah mendekati sesuau hal dengan sistem yang otomatis sehigga memudahkan langkah tersebut. Sistem yang baik akan menguatkan karakter dan perilaku. Penguatan pada sistem tersebut dapat melahirkan sebuah kepercayaan sesorang akan pentingnya sebuah dorongan sikap yang positif. Sikap yang positif tersebut bagian dari psikologi pendidikan yang merubah perilaku seseorang. Perilaku tersebut diawali dengan kematangan individu yang belajar dalam menerapkan sikap-sikap yang berhubungan dengan perilaku manusia.

Psikologi telah menjadi dasar seseorang dalam mengembangkan dan membentuk sebuah nilai, pembelajaran dan sistem pendidikan. Pengembangan diri seseorang dapat dilihat pada aspek pengetahuan, etika dan kecakapan. Dari ketiga hal tersebut dipengaruhi oleh pengembangan tingkah laku, sikap. Sikap dan tingkah laku harus dimotivasi agar menjadi yang lebih energik dan semangat. Ada juga yang penting dalam psikolgi adalah komponen-komponen pembelajaran yang melalui sebuah proses untuk dapat menjadi sebuah neraca siswa masuk dan lulusan peserta didik.

Kurikulum dapat dijadikan sebagai konsep dalam melaksanakan sebuah penilaia peserta didik. Kurikulum saat ini berkembang dan mengikuti perkembangan zaman dan situasi. Perkembangan zaman tersebut menuntut seseorang memiliki kemampuan dalam menghadapi perkembangan dan kemajuan zaman. Kemajuan zaman tersebut diikuti dengan keterampilan, bakat, berfikir maju dan kritis. Kebiasaan berfikiri kritis dalam berperilaku bagian dari refleksi diri yang konsistensi memungkin seseorang untuk menjadi yang lebih baik dan unggul.

\section{Sumbangsih Psikologi pada Manajemen Pendidikan}

Kegiatan pendidikan banyak memerlukan unsur-unsur dari psikologi tersebut terdiri sebagai berikut: seleksi peneriaan baru, planning pendidikan, penyusunan kurikulum, penelitian pendidikan, administrasi kependidikan, pemilihan materi pelajaran, komunikasi dan keaktifan belajar mengajar, pelayanan bimbingan dan penyuluhan, metode mengajar, dan sistem evaluasi (Syah, 2010). Maka dalam aspek psikologi pada manajemen pendidikan memiliki telaah atas fungsi pendidikan untuk mengetahui perilaku peserta didik maupun sekitarnya. Manajemen pendidikan memiliki kajian lima fungsi manajemen yang meliputi lima unsur pokok yang dikemukakan sebelumnya 
pada unsur hakikat manajemen pendidikan.

Tidak semua kelima aspek tersebut bisa diuraikan pada tinjauan pendidikan, akan tetapi ada empat aspek fungsi pendidikan yang dapat diuraikan pada tinjauan manajemen pendidikan pada aspek psikologi. Diuraikan satu persatu dimulai dari perencanaan, yang dimaksud dengan perencanaan yaitu memiliki konten kegiatan pada memenuhi kebutuhan dalam dunia pendidikan. Selanjutnya adalah strategi dalam menjalankan pendidikan harus sesuai dengan kebutuhan pada lingkungan sekitar. Kemudian dilanjutkan dengan menentukan apa program yang cocok pada sekolah tersebut, program yang cocok pada tingkatan pendidikan. Kemudian dalam rangka pengelolaan pendidikan dibutuhkan penyusunan yang tepat dalam perencanaan pendidikan. Penyusunan tersebut harus sesuai dengan kebutuhan jangka pendek, menengah dan panjang. Kebutuhan tersebut direncanakan untuk memperbaiki keadaan dan memenuhi fungsi kebutuhan yang akan datang. Dalam menentukan fungsi pendidikan ada beberapa tahapan yang harus dipenuhi untuk menyampai sebuah tujuan dalam pendidikan. Mulai dari penyusunan program, proses sampai pada pembiayaan dan evaluasi.

\section{Peranan Psikologi dalam Manajemen Pendidikan}

Peranan psikologis bisa menjembatani antara kurikulum pendidikan dan keadaan sikap, sifap peserta didik. Tujuan pada fungsi program yang terdiri dari pendekatan yang diperlukan untuk menetapkan dan mematangkan rencana. Manajemen pendidikan untuk mencapai tujuan maka diperlukan pendekatan psikologis. Pendekatan psikologis dapat memecahkan dan membaca setiap aktivitas-aktivitas perilaku, sikap dalam perencanaan pendidikan yang lebih maju dan baik. Problematika dalam dunia pendidikan yang selalu berkembang dari perilaku peserta didik. Perilaku peserta didik pendekatan yang tepat digunakan dengan pendekatan psikologi sehingga perencanaan, antispasi dapat dipecahkan melalui pendekatan persuasif dengan pembawaan peserta didik.

Pengawasan dan pengendalian bagian dari dua tugas dalam satu fungsi. Artinya pengawasan sesungguhnya dilakukan untuk mengendalikan harapan agar tercapainya sebuah tujuan. Sedangakan pengendalian merupakan cara untuk mengontrol jalannya suatu kegiatan atau program organisasi yang juga dilakukan dalam melakukan penilaian seseorang. Penilaian tersebut dari aspek psikologi seseorang yang bagian dari manajemen. karena manajeme merupapakan kerjasama atau kelompok ornang untuk mencapai tujuan.

Pendeketan tersebut menunjukkan bahwa manajemen dapat dipelajari dan melalui proses kerjasama yang berkembang antara kepempinan dan guru. Manajemen dapat menciptakan interaksi satu sama lain sehingga manajemen dapat dipelajari melalui perilaku organisasi tersebut. Proses pemecahanan masalah adalah suatu upaya yang dapat dilakukan dengan berbagai strategi dan cara masingmasing individu.

Pada masing-masing individu tentunya memili perbedaan watak, 
kompeten, perilaku. Maka perbedaan tersebut harus disikapi dan direncanakan dengan memberikan penanganan yang preventif untuk membaca sifat-sifat pada individu tersebut tentunya dengan strategi dan rencana yang khusus untuk dimasukkan ke dalam kurikulum pendidikan. Peserta didik secara usia mengalami pertumbuhan dan perkembangan dalam perilaku karena peserta didik merupakan bagian dari makhluk yang berada pada perubahan waktu ke waktu. Maka harus sesuai dengan perencanaan yang mengacu kepaada aspek pemahaman psikologi untuk mencapai tujuan yang diharapkan. Baik dengan aspek-aspek pada perilaku objek kemanusiaan.

\section{Fungsi Psikologi pada Manajemen Pendidikan}

Fungsi psikologi dalam manajemen pendidikan mencakup planning sumber daya manusia, fasilitas yang tersedia dalam lembaga pendidikan tersebut. Pengelolaan yang tematik dan integrasi maka akan muncul tahap-tahap kegiatan seperti jenis-jenis dan identitas yang dirumuskan dalam sebuah sistem pendidikan. Maka sistem pendidikan harus mempertimbangkan aspek psikologi untuk memaksimalkan strategi dalam mencapai suatu rencana yang telah disusun seblumnya untuk mencapai tujuan dalam dunia pendidikan.

Aspek psikologi memiiliki fungsi yang dapat memberikan keseimbangan terhadap tugas yang diberikan. Tugas tersebut menjadi pertanggungjawaban untuk dilaksanakan. Lebih lanjut dalam kebijakan untuk menerima dan memberikan kewenangan dalam menjamin implementasi pendidikan.
Implementasi program pendidikan agar tercapainya keberhasilan sangat berkaitan dengan proses komunikasi dua arah yang saling mengisi satu sama lain. Khususnya pada masing-masing individu yang tidak terlepas dari controling dalam manajemen pendidikan. Pelaksanaan manajemen pendidikan melihat kondisi kejiwaan peserta didik dan sumber daya pendidik. Perilaku merupakan gambaran dari sebuah kondisi kejiwaan dan sifat. Perilaku yang baik akan menghasilkan sifat yang baik. Demikian dalam sifat yang baik akan menghasilkan perilaku yang baik pula.

Koordinasi menjadi pertimbangan dalam mengambil sebuah keputusan koordinasi yang baik akan memberkan rasa kebesamaan dan saling percaya. Dalam melaksanakan koordinasi apabila dibarengi dengan emosional negatif maka tidak akan tercapai pelaksanaan program pendidikan dengan baik dan efektif. Koordinasi yang baik pada antar individu tidak akan timbul dengan sendiri tanpa adanya sebuah program dalam pendidikan. Koordinasi antar individu harus diciptakan oleh para pemimpin lembaga pendidikan. Rasa saling percaya dan nyaman dalam lingkungan pendidikan melalui koordinasi yang baik merupakan akibat dari individu yang mendapat stimulus atau rangsagan dari individu tersebut.

Sumber daya manusia dalam lingkungan pendidikan harus dibentuk sikap saling percaya dan nyaman. Sikap merupakan kebutuhan dalam organisasi sekolah untuk melaksanakan program pendidikan. Sikap individu merupakan efek dari perasaan dan emosi. Perasaann dan emosi tersebut menimbulkan kecendrungan atas sikap individu yang merespon sesuatu. Sikap individu yang 
merespon sesuatu merupakan hasil dari reaksi dari dampak yang dirasakan oleh individu. Oleh karena itu sikap sangat berhubungan dengan rasa suka dan tidak suka atas interaksi individu. Interaksi yang baik dalam setiap kegiatan akan menimbulkan perasaan yang sangat menyenangkan. Setiap individu yang merasakan kesenangan akan memberikan dampak kepada lembaga pendidikan ke arah yang lebih baik. Namun sebaliknya apabila terjadi interaksi yang negatif antar individu maka akan berdampak yang tidak baik terhadap lembaga pendidikan.

\section{Sinergi Dan Kontribusi Psikologi pada SDM}

Sinergi dan kontribusi dari masingmasing sumber daya manusia yang berkolaborasi terhadap sarana dan prasarana dilingkungan sekolah memiliki keterkaitan satu sama lainnya dalam bingkai organisasi sekolah yang terstruktur dan sistematis untuk dijalankan pada fungsinya masingmasing.

Organisasi sekolah dilihaat dari berbagai dimensi-dimensi yang memiliki fungsi dan hubungan saling keterkaitan dalam terhadap sasaran-sasaran yang telah disepakati. Pendekatan psikologi dapat membentuk kebiasaan yang baik dalam organisasi pada aspek pengembangan sumber daya manusia. Pengembangan sumber daya manusia bisa melalui pelatihan dan pendidikan. Melalui pelatihan dan pendidikan dengan melihat aspek pskologi maka akan menghadirkan etos kerja yang meningkat. Peningkatan etos kerja sumber daya manusia akan dengan mudah menggapa sebuah visi misi lembaga pendidikan tersebut.

\section{Optimalisasi kinerja dalam} pencapaian visi lembaga pendidikan melalui proses penyusunan dan pematangan program yang dilakukan dengan stimulus terus menerus sampai tercapainya peningkatan program tersebut.dalam pencapaian tersebut diperlukan kebiasaan-kebiasaan yang positif untuk memberikan kenyamanan dan kepercayaan dalam dunia kerja. Kebiasaan tersebut bertujuan untuk meningkatkan keterampilan dalam menjalankan roda organisasi. Keterampilan yang dimaksud adalah meningkatkan dan mengembangkan potensi yang ada pada diri seseorang. Pengembangan diri tersebut dilakukan dengan cara pola-pola yang disusun secara rapi dan sistematis.

Manajemen pendidikan perspektif psikologi memiliki perilaku dan sifat saling memberikan semangat. Semangat yang dimaksud adalah untuk selalu meningkatkan etos kinerja dalam menjalankan program dengan efektif dalam keberhasilan lembaga pendidikan. Motivasi memberikan energi positif terhadap setiap individu. Motivasi yang positif merupakan suatu tekhnik dan strategi dalam memberikan umpan atau stimulus. Ada juga motivasi dengan cara yang dilakukan dengan berpikir keras berupa sebuah ancaman dan desakan untuk memacu individu bekerja dengan lebih giat lagi.

Rasa semangat yang timbul merupakan hasil dari pikiran positif yang didasarkan pada setiap individu saling mempengaruhi tingkah laku seseorang. Dalam berperilaku seseorang dituntut untuk selalu bekerja dengan hasil yang terbaik. Rasa semangat yang timbul 
merupakan akibat dari motivasi setiap individu yang terangkup pada arah dan tujuan tingkah laku. Dalam arah dan tujuan tingkah laku tentunya dikendalikan dengan sikap dan tingkah laku seseorang untuk bersikap dengan gigih dalam aktivitas kinerja. Motivasi dapat memberikan rasa semangat yang membara dalam bertindak.

Sinergi psikologis pemimpin merupakan sebuah simbil yang mengatur dalam pendidikan. Yang mengatur adalah pemimpin dengan wewenang kepemimpinannya melalui intruksi atau persuasi. Seseorang yang ahli atau yang sudah memiliki banyak pengalaman dan pengetahuan yang sangat baik dalam hal memimpin dan mengelolah organisasi atau perusahaan dengan baik untuk mencapai tujuan dari organisasi atau perusahaan tersebut.

tugas yaitu:

Psikologis pimpinan ada empat

1. Tugas yang pertama dan utama adalah memimpin dan mengelolah organisasi atau perusahaan.

2. Tugas kedua yaitu memajukan organisasi dengan cara memaksimalkan segala sumber daya yang sekolah miliki untuk pengorganisasian berkembang secara maksimal

3. Tugas ketiga yaitu bissa mengendalikan masalah serta mencari penyelesaian masalah tersebut.

4. Tugas terakhir atau yang keempat yaitu selalu mengkaji ulang setiap kegiatan yang telah dijakanlakn organisasi atau sekolah.

Psikologis pimpinan mengambil tindakan pembetulan sebagai tanggapan terhadap masalah-masalah yang sebelumnya tak terlihat. Sebagai pengelola sumber

daya,

pimpinan

bertanggungjawab untuk membagikan sumber daya manusia, fisik dan uang. Terakhir pimpinan bertindak sebagai perunding ketika mereka mendiskusikan dan tawar-menawar dengan kelompokkelompok lain untuk memapat keuntungan-keuntungan.

Peran-peran psikologis pimpinan sekolah terbagi menjadi tiga aspek besar yaitu, peran interpersonal, peran informasional dan peran pengambil keputusan. Peran pertama yaitu peran interpersonal, yaitu para manajer dituntut untuk melaksanakan tugas yang melibatkan para staff atau karyawan. Selain itu pimpinan sekolah menjadi perpanjangan tangan dari organisasi ke dunia luar.

Peran kedua yaitu peran informal, yakni pimpinan sekolah adalah pihak yang pertama menerima, mengumpulkan, mengkaji dan menyebar suatu informasi. Manajemer juga mengawasi segala kemajuan dan perkembangan di luar perusahaan atau organisasi.peran ketiga yaitu memutuskan, yakni pimpinan sekolah adalah orang yang bertanggungjawab atas pengambilan keputusa ada penyelesaian masalah organisasi serta untuk memutuskan suatu pilihan untuk organisasi.

Psikologi pada manajerial sangat penting dalam menganalisis situasi. Analisis situasi merupakan langkahlangkah pertama dalam proses penyusunan perencanaan. Langkah ini dilakukan dengan analisis data laporan yang dimiliki oleh organiasi data primer atau data sekunder dari laporan Lembaga sekolah tersebut. Yang datanya diperoleh melalui observasi dan wawancara. Dari analisis data tersebut akan dihasilkan jenis 
data. Selanjutnya data tersebut dianalisis untuk merumuskan masalah-masalah dan dilakukan prioritas masalah berdasarkan kriteria yang telah ditetapkan.

Penentuan tujuan setelah prioritas masalah ditetapakan, manajer menentukan tujuan pemecahan masalah.. sebelum tujuan dan rencana kerja operasional disusun, perlu dipahami beberapa pertanyaan berikut:

1. Berapa besar sumber daya yang dimiliki?

2. Seberapa jauh masalah akan dipecahkan?

3. Kapan target tersebut akan dicapai?

Tujuan mengkaji tersebut adalah mengetahuai kelemahan dan hambatan. Tujuan mengkaji kembali hambatan dan kelemahan sebelumya adalah untuk mencegah atau mewaspadai timbulnya hambatan serupa. Selain itu dapat pula dilakukan prediksi kemungkinan hambatan atau kendala yang terjadi pada saat melaksanakan program kerja.

Psikolgis pimpinan sekolah yang baik akan ada suatu strategi yang baik pada perencanaan. Perencanaan memberikan manfaat yang banyak bagi organisasi, diantaranya adalah menentukan tujuan organisasi sebagai tolak ukur perencanaan, mengukur kemampuan bagi efektivitas dan efisiensi kerja, adanya harapa memperoleh kemajuan, mendapatkan hasil yang telah direncanakan, pengawasan penilaian terhadaphasil yang dicapai.

Menghilangkan ketidakpastian adalah alat untuk mencegah pemborosan tenaga, pikiran, waktu, dan biaya. Perencanaan tersebut dengan syarat mudah mengukur prospek ke depan dalam suatu organisasi. Tentunya dapat menentuka pilihan dalam memecahkan masalah, standarisasi kegiatan adalah prioritas kebutuhan suatu organisasi. Hal lain tentunya perencanaan dapat dijadikan dasar penjabaran program kerja secara sistemaris dalam suatu organisasi. Pembagian tugas dan keahlian yang akurat akan melahirkan produktivis manajemen yang baik.

Psikologi memberikan kontribusi berupa gambaran yang jelas dan lengkap mengenai seluruh rangkaian kegiatan. Dari seluruh rangkaian tersebut memiliki beberapa langkah-langkah operasional sebagai berikut:

1. Tujuan organisasi sekolah harus dipahami oleh staf

2. Membagi habis pekerjaan dalam bentuk kegiatan -kegiatan pokok

3. Menggolongkan kegiatan pokok kedalam satuan kegiatan yang praktis

4. Melakukan suatu hal yang prioritas agar dapat dilakuan dan menyediakan factor pendukung untuk melaksanakan tugasnya.

5. Pembagian tugas untuk perorangan dan kelompok

6. Hubungan organisator antar anggota suatu organisasi

7. Pemanfaatan fasilitas fisik yang dimiliki organisasi sekolah.

Pengawasan dan pengendalian merupakan bagian dari dua tugas yang menjadi satu yaitu fungsi. Artinya memang pengawasan sesungguhnya dilakukan untuk mengendalikan harapan agar tujuannya tercapai. Sedangkan pengendalian merupakan cara untuk mengontrol jalannya suatu kegiatan atau program organisasi yang juga dilakukan melalui pengawasan. Pengawassan pada suatu organisasi atau Lembaga harus peka dengan rumusan tujuan organisasinya. 
Serta selalu mengembangkan pendekatan partisipasif untuk mencapai tujuan tersebut.

Psikologi dan manajemen pendidikan merupakan suatu kerjasama yang mencermikan bagian dari sekelompok orang untuk mencapai tujuan organisasi. Pendekatan tersebut menunjukkan manajemen dapat dipelajari melalui proses kerjasama yang berkembang antara pimpinan dan anggota atau staf. Manusia sebagai man power manajemen akan menimbulkan interaksi satu sama lain sehingga manajemen dapat diterapkan melalui suatu ilmu kejiawaan atau psikologi tersebut. Peranan psikologi dapat menuntut seseorang pimpinan sekolah untuk selalu mengembangkan diri dengan mempelajari ilmu-ilmu yang terkait dengan tugasnya. Proses pemecacahan masalah adalah suaru upaya yang dilakukan dengan berbagai strategi atau pendekatan untuk menyelesaikan setiap permasalahan yang terjadi secara efektif dengan meminimalkan kemungkinan dampak negatif yang ditimbulkan.

Manajemen ditinjau dari aspek psikologi yang berkaitan dengan perilaku manusia yaitu manajemen dengan pengorganisasian yang dijalankan oleh manusia sebagai man power. Manajemen dapat dipelajari dari perilaku manusia yang menjalankan manajemen tersebut. Manajemen sebagai suatu proses adalah manajemen yang dinilai dari bagaimana orang-orang di dalam manajemen itu menjadalankan proses untuk memanajemenkan sesuatu.

Sebagai ilmu manajemen memiliki teori dan kerangka pikir yang sudah teruji, terutama berhubungan dengan teori manajemen ilmiah, organisasi klasik dan teori organisasi. Teori manjemen tersebut dapat memfokuskan pada kajian yang penting dalam keberadaannya dan peran pimpinan sekolah dalam suatu organisasi. Pengendalian suatu organisasi secara langsung berkaitan dengan fungsi-fungsi kepemimpinan dalam organisasi manajemen sekolah. Sebagaimana perlunya menguraikan secara detail tentang kedudukan, tugas dan fungsi dari pimpinan sekolah.

\section{Kesimpulan}

Hakikat manajemen pendidikan memiliki titik fokus pada empat elemen dalam sendi psikologi diantaranya adalah perencanaan, organisasi, koordinaasi dan motivasi. Perencanaan merupakan pemetaan dalam kebutuhan suatu organisasi. Kebutuhan organisasi direncanakan dengan strategi yang khusus dalam menjalankan program pendidikan. Dalam menjalankan program pendidikan tidak terlepas dengan memperhatikan aspek perilaku setiap individu.

Kajian psikologi merupakan sebuah sikap yang saling melengkapi dalam mempengaruhi sebuah sikap yang didasarkan pada energi positif dengan tujuan untuk saling mempengaruhi dalam setiap individu. Menyebarkan virus-virus yang positif dalam setiap individu untuk saling mengisi kekurangan satu sama lain. Rasa semangat dapat memberikan nilainilai yang baik dalam menjalankan program pendidikan secara maksimal dalam mencapai sebuah tujuan pendidikan.

Sumbangsih Psikologi dalam manajemen pendidikan tersebut terdiri dari aspek individu merupakan bidang disiplin psikologi yang tergabung dalam wadah organisasi. Sikap individu 
merupakan sebuah gambaran yang muncul pada organisasi misalnya pada kebiasaan yang baik dalam bekerja. Aspek psikologi menekankan pada kebiasaan yang selalu berinteraksi dalam komunikasi yang matang dalam menentukan kebijakan. Kebijakan ditentukan dengan interaksi yang terbuka dan tidak ditutupi. ${ }^{* * *}$ 


\section{Daftar Pustaka}

Jahja, Y. (2011). Psikologi perkembangan. Jakarta: Kencana.

Jalaluddin. 1997. Filsafat

Pendidikan. Jakarta: Rajawali Pers.

Khodijah. 2011. Psikologi

Pendidikan. Palembang : Grafika

Telindo Press.

Mudyahardjo, R. 2006. Filasafat Ilmu

Pendidikan. Bandung: Remaja

Rosdakarya.

Mudyahardjo, R. 2010. Filsafat Ilmu

Pendidikan Suatu Pengantar. Bandung:

Rosdakarya.

Muhaimin, M. A. (2015). Manajemen

Pendidikan (Aplikasinya dalam

Penyusunan Rencana Pengembangan

Sekolah/Madrasah). Jakarta: Prenada

Media.

Pananrangi, H. A. R. (2017). Manajemen

Pendidikan (Vol. 1). Makasar: Celebes

Media Perkasa

Pieter, H. Z. (2017). Pengantar psikologi dalam keperawatan. Jakarta: Kencana.

Purwanto, N. 2010. Psikologi Pendidikan.

Bandung : Remaja Rosdakarya.

Riyadi, I. (2019). Manajemen Diversity dan

Kesetaraan dalam Lembaga

Pendidikan Islam: Suatu Analisis

Realitas Sosial. Mawa'izh: Jurnal

Dakwah Dan Pengembangan Sosial

Kemanusiaan, 10(2), 231-247.

Roqib, M. (2009). Ilmu Pendidikan Islam;

Pengembangan Pendidikan Integratif di

Sekolah, Keluarga dan Masyarakat.

Yogyakarta: LKIS Pelangi Aksara.

Sa'ud, S. 2009. Perencanaan

Penddidikan. Bandung: Rosdakarya.
Setiadi, I. (2016). Psikologi positif:

Pendekatan saintifik menuju kebahagiaan.

Jakarta: Gramedia Pustaka Utama.

Soebagio, A. 2002. Manajemen Pendidikan

Indonesia. Jakarta: Ardadizya Jaya.

Sufyaeman. 1995. Kapita Selekta:

Manajemen Pendidikan. Bandung:

Alfabeta

Sufyarma. 2003. Ka pita Selekta: Manajemen Pendidikan. Bandung: Alfabeta.

Susanto, A. (2016). Manajemen peningkatan kinerja guru konsep, strategi, dan implementasinya. Jakarta: Prenada Media.

Sutisna, O. 1983. Administrasi pendidikan:

Dasar teori untuk praktek profesional. Bandung: Angkasa.

Syafi'i, A. (2012). Dinamika perkembangan sistem kepercayaan lokal di Indonesia.

A. S. Mufid (Ed.). Jakarta:

Kementerian Agama RI, Badan Litbang dan Diklat, Puslitbang Kehidupan Keagamaan.

Syah, M. 2010. Psikologi Pendidikan. Bandung: Remaja Rosdakarya

Taufiq, M. I. (2007). Panduan lengkap dan praktis psikologi Islam. Yogyakarta: Gema Insani.

Tilaar, H.A.R. 2006. Manajemen Pendidikan Nasional. Bandung: Remaja

Rosdakarya.

Woodworth. 1955. Psychology A Study Of Mental Life. London: Methuen \& Co.Ltd. 